\title{
THE ROLE OF BALADA CENDERAWASIH TRADITIONAL DANCE OF PAPUA
}

\author{
Sri Winarsih \\ English Literature Department \\ Universitas Musamus \\ sriwinarsih@unmus.ac.id
}

\begin{abstract}
Balada Cenderawasih is a traditional dance of Papua which is performed by a group of dancers in the costumes resembling beautiful Paradise birds. The dance is often performed in many important events in Merauke. This study aims to find out the role of Balada Cenderawasih as a kind of ballad from Papua beyond an art show. Two subjects were studied; the dance and the owner of traditional dance studio. Through overt observation over the dance, and semi structured interview with the owner of traditional dance studio, it was collected the data and were analyzed using Spradley qualitative model. The study shows the roles of Balada Cenderawasih are as; 1) Cultural identity; through the motions, language and symbols; 2) Regional wealth, both material and cultural heritage; through the show includes costumes, musical instruments and the dancer attributes; and 3) Environmental protection; through the values include moral, religious and education.
\end{abstract}

Keywords: balada cenderawasih, ballad, role, traditional dance

\section{INTRODUCTION}

Changes occur in almost all aspects of human life such as cultural changes and technological advances that occur only in a moment. It is as the result of the phenomenon of globalization which has brought human life to an era of infinite worlds. Every change certainly brings good and bad impacts. One of the beneficial effects is the more advanced living facilities that can ease the burden of human work. However, there are aspects of life that are neglected and threatened to disappear as a result of the advancement of human civilization, such as the exclusion of local culture due to the entry of foreign cultures.

It is inconceivable if a generation of ecological communities no longer recognize the identity and products of their mass culture because of the impact of the current of globalization. It cannot be denied that this fact has already taken place. Culture as a form of identity of certain national and indigenous peoples at

\section{British, Jurnal Bahasa dan Sastra Inggris}


this time tends to be forgotten. Like traditional dance, it is an element of culture. At present, many new generations prefer the modern dance to the traditional one. Traditional dance are included into local wisdom, as well as other cultural elements as mentioned by Koentjaraningrat (1980: 204) namely language, knowledge systems, social organizations, living equipment systems and technology, livelihood systems, religious systems, and arts.

The task of people as an ecological community is to preserve the culture that is owned. Not solely the fault of the new generation who do not know the culture of their ancestors, but it is the responsibility of every community holding the culture itself to protect, preserve and inherit ancestral culture through traditional activities such as traditional dances.

In Indonesia, one of the ecological communities that is still very strong in maintaining its cultural identity is the people of Papua. Papuan local wisdom is reflected in traditional dances, traditional houses, traditional clothes, ritual ceremonies, languages and livelihood systems. The Papuan people themselves are known to always try to preserve and maintain the existence of existing customs so that they can be passed on to the next generation. Efforts are made by the Papuan people in preserving their culture such as preserving traditional dances. One of the best dances is Balada Cenderawasih.

The question that then arises is what is the role of traditional dance beside to maintaining the culture of a civilization? Are there other contributions made by traditional dances to the community or the culture itself?

A research conducted by Smith (2018: 10) found that Karen traditional dance has a role as a vehicle to form identity and establish social relations after a forced migration incident. Those forced to migrate to a foreign country may face challenges to their sense of identity and belonging when immersed in a society that is unfamiliar to them. In other words, traditional dance helps them find relatives and form a Karen community in a new place. A similar study was also carried out by Persaud (2011: 18) who revealed that Ghanaian traditional dance serves to provide understanding and experience of community concepts that must be understood by Western people as well as by Non-Western people. One of the 
traditional dances is Astiagbekor which gives an overview of the concept / theory of marriage in western culture. While Mataga (2008: 98) mentioned in his research result that the Mbende/Jerusarema dance from Zimbabwe plays as a symbol of struggle and survival of the community through the turbulent history. Beside that the dance shows the aesthetics values through the material culture in two ways; dancer costumes and music instrument. The aesthetics values are then functions in tourist attraction.

Based on the three studies, the researcher then felt interested in finding the role of Balada Cenderawasih, considering that the dance is one of the most widely performed and very familiar traditional dances among Papuans. The study aims to determine the role of the Balada Cenderawasih traditional dance of Papua for the people. By finding out the role of the dance the audiences will appreciate a dance more than a show and to keep its existence sustainable.

Balada Cenderawasih dance is a traditional Papuan dance that is often performed in a celebration event. It is performed by a group of dancers in the costumes resembling beautiful Paradise birds.Each regency in Papua has a version of the dance respectively. As in Merauke, the the dance is often performed in celebrations such at the public party at the anniversary of the city of Merauke or art performances at schools in the city of Merauke. The existence of traditional Papuan dance studios plays an important role in the preservation of traditional dances like this. One of the dance studios that often features the Balada Cenderawasih dance is Dahuke'he dance studio Merauke.

\section{RESEARCH METHOD}

This study is qualitative with the object of study is in the natural setting in which Balada Cenderawasih was performed as usual on the stage without any interference from the outsiders, so it is also called naturalistic study as Prastowo (2012: 359). Through overt observation over the dance performance, and semi structured interview with the owner of traditional dance studio as the informant, the descriptive data were collected analyzed using Spradley qualitative model; domain, taxonomy, components, and theme.

\section{British, Jurnal Bahasa dan Sastra Inggris}


The Balada Cenderawasih studied by the researcher was performed in about 16 minutes by the dancers and managed by Dahuke'he studio Merauke Papua located on Jl. Garuda Spadem. The informant of the source data is the head of Dahuke'he studio.

\section{RESEARCH FINDING AND DISCUSSION}

Balada Cenderawasih a traditional dance of Papua is often performed in many events and is very well known by people in Papua as it is in Merauke. Of course the existence of the dance has an important role for the life of the community or the culture. This role can be found through a study and the results show that the roles of Balada Cenderawasih for the people of Merauke Papua are; 1) Cultural Identity, 2) Regional Wealth, and 3) Environmental Protection. As explained in the following discussion:

\section{Cultural Identity}

Giorgios (2018: 108) defined "Tradition is the knowledge that has been stored within a long period of time in a society of people and passes down from generation to generation. This knowledge has to do with songs, dances, fairy tales, dramatic performances etc." From the meaning, it is known that tradition is the habituation or same pattern in a community that forms a culture. The culture is reflected in the traditions such as in songs, dances, rituals, which eventually become an identity of a community. As Balada Cenderawasih is a traditional dance that shows the cultural identity of the Papuan people through motion in dances by dancers, language in the song lyrics, and symbols contained in the dance.

\section{a. Motion}

The dancers' motions were very detailed, not only describing the story of a group of Cenderawasih birds, but explicitly describing some traditions that were cultural markers of the Papuan people, especially Merauke.

- Formation of paired and group birds shows cultural rule applied in the community of Papuans that they live in small groups led by a leader calls ondoafi who has a partner to multiply offspring.

\section{British, Jurnal Bahasa dan Sastra Inggris}


- Nggatsi motion is a typical Papuan motion that is almost presented in every traditional Papuan dance, which is a motion integrated with the earth. This shows a cultural identity that indigenous Papuans live in nature such as looking for food from the forest either hunting or picking food. Nggatsi is the activity of Papuans whispering to the earth as a prayer and gratitude to the Almighty.

- Hunting with arrows is the motion of a hunter who is looking for birds for his survival. This is a real portrait of the culture of Papuans to make a living by hunting.

\section{b. Language}

The song lyrics in Balada Cenderawasih dance produced by Dahuke'he dance studio are sung in Marind language, the native language of Merauke tribe, Marind people. So it clearly refers to the identity of native Merauke people.

c. Symbol

Symbols in Balada Cenderawasih dance derive from color and artifacts used during the dance performance.

- Color is dominated by dark brown and soft brown with little touch of rainbow color. It symbolizes the identical ecosystem lived only in Papua, the paradise birds. The bird is endangered animals protected by the government.

- Carving on the body; The style of carving on the dancer's body basically shows the identity of the clan, but the Dahuke version uses a common style, the carving style of the Marind tribe in general. So in this discovery, the carving style on the dancer's body shows the identity of ethnic Papuan groups.

- Crown; male dancers's crown is made of cassowary feathers, while women's is made of paradise birds' feathers. This shows gender identities. The cassowary symbol signifies virility, while Cenderawasih signifies beauty. Besides that the crown has a symbol as an identity of social status in which the leader (ondoafi) used different size, color, and model of

\section{British, Jurnal Bahasa dan Sastra Inggris}


crown from other dancers. This shows their position / position in the composition of different communities. But it must be underlined that at present day the use of real paradise bird's feather is forbidden. So it is made of imitation good.

Related to the results of studies revealed by Smith (2018), Persaud (2011) and Mataga (2008) as mentioned before, there is similarity of the roles of traditional dance, that is dealing with cultural issues. But, the cultural issue found in Balada Cenderawasih dance is more related to Persaud's rather than to Smith's and Mataga's. In Smith's and Mataga's revealed that the traditional dances they studied play the role as survival existence of a community after the hard situation. While, in Persaud's it is revealed that it gives understanding about the concept of western community to the people. And here, one of the roles of Balada Cenderawasih is to show the cultual identity of native people of Merauke as one of Papuan tribes. Reminding that there are many outsiders coming and living in Papua, so the dance plays the role as introducing their culture to the outsiders who then live in Papua together with them.

As borrowing the concept of local wisdom expressed by Keraf (2010) as cited in Kafiar (2013: 38) that human survival is basically divided into groups that are characterized by an identity and each identity contains the values of their respective significance, it can be seen that Papuan preserve their culture to maintain their identity among the rapidity of development era and the open opportunity of the coming outsiders' influences.

\section{Regional Wealth}

The meaning of regional wealth here means both material wealth and cultural heritage. The Balada Cenderawasih dance is one of the dances most often performed at important events in Merauke, Papua. Some contingents from Merauke have even been invited to perform outside Papua. This certainly gives pride to the local government of Merauke because it can lift the name of the region up and also show the cultural property belongs to Merauke. Eventually, those many arts and culture will attract visitors to visit Merauke which certainly has a good impact on economic sector in Merauke. This happened because Balada 
Cenderawasih dance that showed costumes, musical instruments and the attributes of the dancer provided a special attraction for guests visiting Merauke so that they would look for these objects to become souvenirs. Cultural objects such as crowns, arrows, and tifa are sold by many indigenous Papuans, which helps the economy of the Papuan people.

That role is the same as Mataga's (2018) results which mentioned that Mbende dance from Zimbabwe can atrract the tourists by the aesthetics values in the dance through the dancer costumes and music instruments.

\section{Environmental Protection}

"When dancing, one actually "talks" with their self and with the community at the same time. In this way the community reinforces its cohesion, gets connected with their past where values derive from, gets amused and delivers folk tradition by repetition, continuity and word of mouth (Tyrovola, 1999 as cited in Giorgios 2018: 105). Based on these statements, it can be said that a dance contains certain message to be conveyed to the audience. The message can be searched by finding out the values in the dance.

Thome (2015: 47) convinced that the main points of values are considered as motivation for people to do right in life. It means that the values have the role to remind people about what is right and what is wrong. Hence, the values in Balada Cenderawasih are found as follows;

\section{a. Moral}

Churchill (1982) as cited in Chowdury (2016: 1) stated that "Moral refers to human behaviour where morality is the practical activity." Moral values covers a system of various customs and beliefs which every individual keeps in order to live long and to avoid bad luck on them and others. It is the core of all values in the dance as it derives from the conclusion of the chronological story of the dances.

The story deals with the society of Papua recently. The moral values delivered to society through the dance are reminding people about the impact of illegal hunting of protected fauna due to the risk of extinction of Paradise birds in Papua, especially in Merauke. The dance is representing the voice of

\section{British, Jurnal Bahasa dan Sastra Inggris}


the birds which are at threat of shooting arrows by random hunters everyday that brings them to the risk of extinction. A case study conducted by Yekbat and Maturbongs (2015) revealed that there are still many illegal trades in wildlife including Paradise birds.

The local government of Merauke has actually established regulations for Paradise birds and other animals in the of National Wasur Park Merauke. So the moral values in the Balada Cenderawasih is about obeying regulation, preserving nature, loving God's creatures.

\section{b. Religious}

Religious elements found in Balada Cenderawasih dance are;

- Grateful; Nggatsi (Marind) movement is a typical Marind tribal movement that describes the movement of united with the earth. It happens in the scene before the birds having fun with the partner. It describes the sacred ritual which is basically an activity to whisper to the earth as an expression of gratitude to God for the happy day and life opportunity they have in safety natural environment without any danger;

- Regretful; The regretful hunter is the scene when the hunter is regret after shooting his arrows to the bird. The hunter is crying and breaking his arrow. It is a kind of religious element that describes the expression of regret after doing mistakes.

\section{c. Educational}

Inner education as a tool to determine human behavior in social life forms attitude or temperament. With the existence of character education, every human being stands as an independent human being, who can rule or control himself (independently) (Dewantara, 1977: 24). The regret from the hunter after killing the leader bird shows the character education how people remember the mistakes and change the attitude. In this case, the audiences can remember to not do what the hunter did which ended with regret.

In addition, (Megan Browning. 2009: 13) give another concept of educational values of traditional dance as "The role of traditional dance is educating the society and especially the new generation." The statement is in line with Siregar 
(2002: 6) argues that culture is obtained from learning not biologically inherited or inherited through unsurgenetic, so if not learned is destroyed. Those mean that traditional dance as a culture can give people an education through learning.

\section{CONCLUSION AND SUGGESTION}

Balada Cenderawasih as a traditional dance of Papua has roles for the community. The contribution in showing native Papuan's cultural identity, lifting up the economics of native Papuan and regional government prestige, and delivering the message to audiences about prohibition of illegal hunting for protected animals due to the environmental protection are revealed by learning the roles of the dance through a research. The process of learning a culture for a researcher, especially those from outside the culture, is a golden opportunity to explore the treasure that will become a legacy. However, the audiences must appreciate the dance more than just a show on the stage after finding the values in it.

\section{ACKNOWLEDGMENT}

The writer would like to express gratitude to Direktorat Riset dan Pengabdian Masyarakat - Direktorat Jenderal Penguatan Riset dan Pengembangan Kementerian Riset, Teknologi, dan Pendidikan Tinggi for supporting her in conducting the research by the grant, to Rector of Musamus University for the support in giving opportunity and motivation to be actively in conducting Tri Dharma.

\section{REFERENCES}

Browning, M. 2009. Shake it: A Study of Traditional Dance and Drumming in Tanzania with the African Traditional Dance Group. SIT Tanzania Wildlife Ecology and Conservation.

Chowdhury, M. 2016. "Amphazising Morals, Values, Ethics, and Character Education in Science education and Science Teaching." Malaysian Online Journal of Educational Science. Vol. 4 (2), pp. 1-16.

Dewantara, K. H. 1977. Karya Ki Hajar Dewantara. Yogyakarta: Majelis Luhur Taman Baca.

Georgios, L. 2018. "The Transformation of Traditional Dance from Its First to Its Second Existence: The Effectiveness of Music -Movement Education and creative Dance in the Preservation of Our Cultural Heritage". Journal of Education and Training Studies. Vol. 6 (1), pp. 104-112.

\section{British, Jurnal Bahasa dan Sastra Inggris}


Kafiar, F. P. 2013. "Kearifan Lokal Suku Amungme Dalam Pengelolaan Sumber Daya Alam dan Lingkungan di Kabupaten Mimika Papua". Jurnal Ekosains. Vol. 5 (1), pp. 35-43.

Koentjaraningrat, (1980). Sejarah Teori Antropologi 1. Jakarta: Universitas Indonesia.

Mataga, Jesmael. 2008. "Beyond the Dance: a Look at Mbende (Jerusarema) Traditional Dance in Zimbabwe". International Journal of Intangible Heritage. Vol. 3, pp. 96-102.

Persaud, D. 2011. Traditional Ghanaian Dance and Its Role in Transcending Western Notions of Community. Richter Research Abroad Student Scholarship. Retrieved from http://scholar.oxy.edu/rrap_student/2. , pp. 124.

Prastowo. 2012. Metode Penelitian Kualitatif: dalam Perspektif Rancangan Penelitian. Yogyakarta: Ar-Ruzz Media.

Siregar. 2002. “Antropologi dan Konsep Kebudayaan”. Jurnal Antropologi Papua. Vol. 1(1), pp. 1-7.

Sjarkawi. 2008. Pembentukan Kepribadian Anak. Jakarta: Bumi Aksara.

Smith, Y. J. 2018. "Traditional Dance as a Vehicle for Identity Construction and Social Engagement after Forced Migration”. Societies, Vol. 8 (67), pp. 110.

Thome, H. 2015. Values, Sociology of, International Encyclopedia of the Social \& Behavioral Sciences, 2nd edition, V 25. Oxford: Elsevier.

Yekbat, M. and Maturbongs, R. G. 2015. Burung Cenderawasih: Potensi Ekowisata di Selatan Papua. Jayapura: WWF Indonesia-Program Papua. 